\title{
Dominant vertebral artery occlusion during ipsilateral head tilt
}

田

Figure Dynamic cerebral angiography

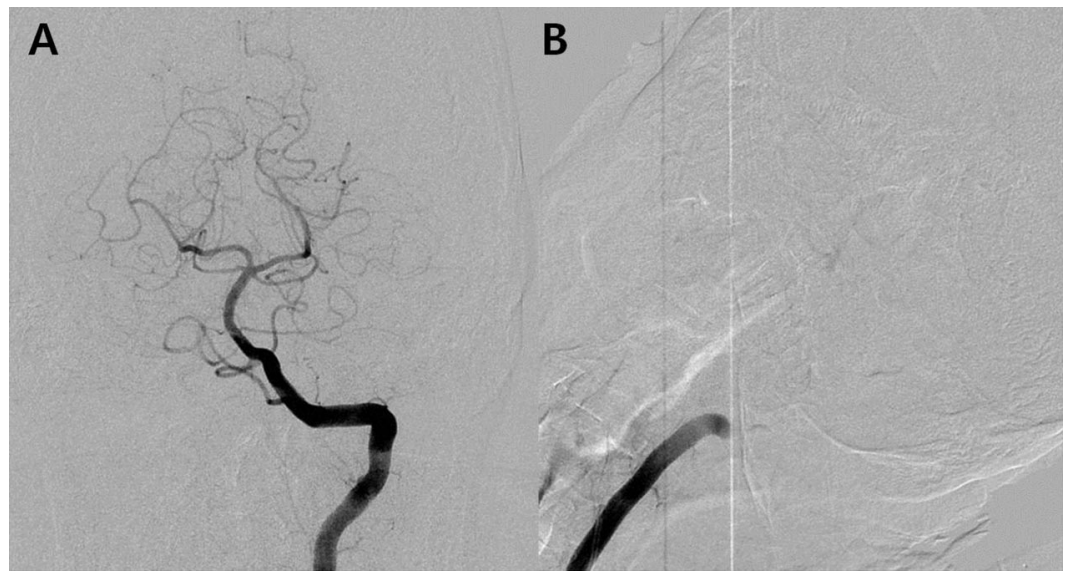

Dynamic cerebral angiography shows patent left vertebral artery in the neutral position (A), which is completely occluded at the atlantoaxial junction during head tilt to the left (B).

A 29-year-old man had paroxysmal vertigo, tinnitus, and visual blurring during head tilt to the left. During leftward head tilt, there was downbeat nystagmus with small leftward horizontal and torsional components (video on the Neurology ${ }^{\circledR}$ Web site at www.neurology.org). Horizontal head rotation did not elicit nystagmus. Magnetic resonance angiography revealed a hypoplastic right vertebral artery (VA). Dynamic angiography during left head tilt documented occlusion of the left VA at the atlantoaxial junction (figure). Cervical CT showed no bony abnormalities. Aspirin was started with instructions to avoid head tilt. Most patients compress the dominant VA with horizontal head rotation to the opposite side, ${ }^{1,2}$ but ipsilateral head tilt may also cause dominant VA occlusion.

\section{J.-H. Choi, MD, M.-J. Kim, BSc, T.-H. Lee, MD, I.S. Moon, MD, K.-D. Choi, MD, Busan; J.S. Kim, MD, Bundang,} Korea

Disclosure: Dr. J.-H. Choi, M.-J. Kim, Dr. Lee, Dr. Moon, and Dr. K.-D. Choi report no disclosures. Dr. Kim served as an Associate Editor for the Journal of Korean Neurological Association, serves as an Associate Editor of Frontiers in Neurotology and on the editorial boards of the Journal of Korean Society of Clinical Neurophysiology, the Journal of Neuro-ophthalmology, and Frontiers in Neuroophthalmology; and receives research support from SK Chemicals, Co. Ltd.

Address correspondence and reprint requests to Dr. Kwang-Dong Choi, Department of Neurology, College of Medicine, Pusan National University, 1-10 Ami-dong, Seo-gu, Busan, 602-739, Korea; kdchoi@medimail.co.kr

Supplemental data at www.neurology.org
1. Choi KD, Shin HY, Kim JS, et al. Rotational vertebral artery syndrome: oculographic analysis of nystagmus. Neurology 2005;65:1287-1290.

2. Brandt T, Baloh RW. Rotational vertebral artery occlusion: a clinical entity or various syndromes? Neurology 2005;65:11561157. 


\section{Neurology}

\section{Dominant vertebral artery occlusion during ipsilateral head tilt \\ J.-H. Choi, M.-J. Kim, T.-H. Lee, et al. \\ Neurology 2011;76;1679 \\ DOI 10.1212/WNL.0b013e318219fb6c}

\section{This information is current as of May 9, 2011}

\section{Updated Information \& Services \\ Supplementary Material \\ References \\ Subspecialty Collections}

Permissions \& Licensing

Reprints including high resolution figures, can be found at: http://n.neurology.org/content/76/19/1679.full

Supplementary material can be found at: http://n.neurology.org/content/suppl/2011/05/07/76.19.1679.DC1

This article cites 2 articles, 2 of which you can access for free at: http://n.neurology.org/content/76/19/1679.full\#ref-list-1

This article, along with others on similar topics, appears in the following collection(s):

\section{All Cerebrovascular disease/Stroke}

http://n.neurology.org/cgi/collection/all_cerebrovascular_disease_strok e

All Clinical Neurology

http://n.neurology.org/cgi/collection/all_clinical_neurology

All Imaging

http://n.neurology.org/cgi/collection/all_imaging

All Neurotology

http://n.neurology.org/cgi/collection/all_neurotology

Information about reproducing this article in parts (figures,tables) or in its entirety can be found online at:

http://www.neurology.org/about/about_the_journal\#permissions

Information about ordering reprints can be found online:

http://n.neurology.org/subscribers/advertise

Neurology ${ }^{\circledR}$ is the official journal of the American Academy of Neurology. Published continuously since 1951, it is now a weekly with 48 issues per year. Copyright Copyright (? 2011 by AAN Enterprises, Inc.. All rights reserved. Print ISSN: 0028-3878. Online ISSN: 1526-632X.

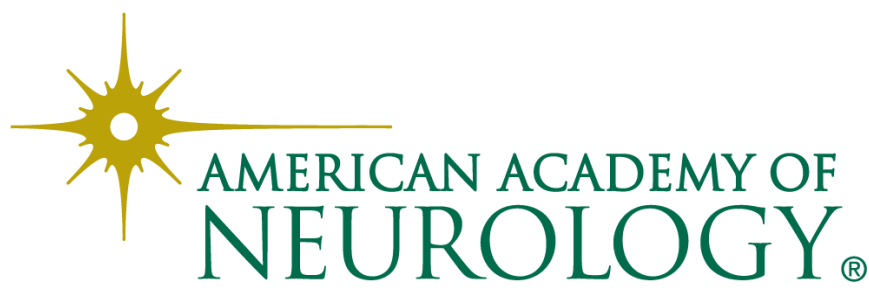

